\title{
FUTURE LIVING ARRANGEMENT FOR AGING PARENTS AND ITS ASSOCIATED FACTORS
}

\author{
Rahmi Setiyani, Made Sumarwati, Dian Ramawati
}

Nursing Department, Health Sciences Faculty, Jenderal Soedirman University

\begin{abstract}
Shift in demographic structure in Indonesia has raised concern over number of issues, including change in living arrangement of older people. The purpose of this study is to examine adult children's plan of future living arrangement for elderly parent and its associated factors. A cross sectional study was conducted among 300 young adults in Central Java, Indonesia. Descriptive statistics, Chi-Square and Fisher exact test were used to analyze the data. Majority of respondents (97.3\%) preferred parents to live at home, in multi-generational household with children and/or grandchildren $(84.5 \%)$ in their old age. The choice was significantly influenced only by children gender $(p=0.000)$. In certain circumstances, living in multigenerational household still became adult children's favorable option of living arrangement for elderly parents. The living arrangement option was more likely to be influenced by children gender. Further researches are needed to investigate which best living arrangement that support older people well-being.
\end{abstract}

Key words: Adult children, extended family, elderly, intergeneration, well-being

\section{ABSTRAK}

Perubahan struktur demografi di Indonesia telah memunculkan kekhawatiran tentang berbagai hal, termasuk perubahan pola penetapan bertempat tinggal lanjut usia. Penelitian ini bertujuan untuk mengidentifikasi rencana anak yang telah dewasa tentang pola penetapan bertempat tinggal untuk orangtua yang berusia lanjut di masa mendatang dan faktor-faktor yang berkaitan. Penelitian dengan desain potong lintang dilakukan pada 300 individu usia dewasa muda di Jawa Tengah, Indonesia. Data dianalisa menggunakan statistik deskriptif, uji Chi-Square dan Fisher Exact. Mayoritas responden $(97.3 \%)$ menginginkan orangtua saat mereka berusia lanjut untuk tinggal di rumah, di dalam rumah tangga multi-generasi dengan anak dan/atau cucu (84.5\%). Pilihan penetapan bertempat tinggal secara signifikan hanya dipengaruhi oleh jenis kelamin anak (nilai $p=0.000$ ). Tinggal di rumah tangga multi generasi tetap menjadi pilihan anak yang telah dewasa tentang pola bertempat tinggal bagi orangtua yang berusia lanjut. Pilihan tersebut dipengaruhi oleh jenis kelamin anak Penelitian lebih lanjut dibutuhkan untuk mengidentifikasi pola penetapan bertempat tinggal terbaik yang mendukung kesejateraan lanjut usia.

Kata kunci: Anak yang telah dewasa, keluarga besar, lansia, antar genenerasi, kesejahteraan 


\section{BACKGROUND}

Like many other countries in the world, Indonesia is experiencing rapid increase in the proportion of older people in the population, known as population aging. The United Nations, (2017b) reported that the number of people age 60 years old and over in Indonesia in 2015 was about $8.6 \%$ of the population. The number is projected to double and reach $19.2 \%$ in 2050.

Population aging has caused changes in many aspects of life, including living arrangement of older people. Living arrangement refers to which older people live and the composition of their households. It is then classified into four mutually: alone, with spouse only, with children and other (United Nations, 2005).

The large number of older people in Asia is still living in intergenerational coresidential household. Survey reported that majority of elderly in Indonesia are living in intergenerational co-residential household (70\%). Meanwhile, about 20\% are living with spouse only and the rest are living alone (Badan Pusat Statistik (BPS), 2018). However, there is a trend towards independent living as a result of the broader demographic, economic and social changes. With the increasing urbanization and globalization, it is quite common for adult children to move from rural to urban areas and live separately in search of improved work and living opportunities (Kadar, Francis, \& Sellick, 2013). This put the availability of potential care givers within the family into question.

Living arrangement for older people has been an emerging aging related issue. When older people gradually lose their independence due to aging process, they definitely need assistance from others to perform daily activities and fulfill their needs. The likelihood of disability also increases significantly with age, with 26.0 percent older population being affected (United Nations Population Fund, 2014). Thus, with the expected decline in family sizes and availability of support from families, there would be need to prepare alternative care arrangements and provide necessary assistance to such older people in order to ensure their wellbeing (United Nations Population Fund, 2014).

Moreover, living arrangement has been linked to older people's health outcomes. Previous studies in Asia contexts suggested that intergenerational co-residence was beneficial to older people's psychological wellbeing and selfrated health (Teerawichitchainan, Pothisiri, \& Long, 2015; Zhou et al., 2018). However, a study in US context found that older adults co-residing with others related/unrelated were likely to be in poor health, had serious psychological distress and limitations in activities of daily living (ADLs), and a greater number of health conditions compared with older adults living with a spouse/partner (Weissman \& Russell, 2018). These conflicting evidences indicated that many factors interplay between these two phenomena. Previous studies suggested that decision surrounding living arrangement was influenced by a variety of factors including cultural norms, parent's characteristics and caregiving needs (Chen, 2011; Guo, Konetzka, Magett, \& Dale, 2014; Teerawichitchainan et al., 2015; Zhang, Gu, \& Luo, 2014).

Few studies about living arrangement have been conducted in Indonesia context (Johar \& Maruyama, 2010, 2014; Schröder-Butterfill \& Tengku Syawila, 2014). However, little is known about future living arrangement's preference, especially from the view of adult children who culturally expected to provide supports for parents in their old age. Thus, knowing the future trend of living arrangements for aging parents can provide necessary helps to identify vulnerable groups of older people that need to be prioritized in health care. This study is undertaken to examine adult children's choice of future living arrangement for elderly parent and its associated factors.

\section{METHODS \\ Participants}

This study used a cross-sectional design. The study was conducted on sample of highly educated adults as represented by undergraduate students of a state university in Central Java. 
University students were chosen as sample because they were quite diverse in demographic characteristics and at their ages they likely already or soon have elderly parents. A total of 300 samples were recruited using two stages of sampling; first was quota sampling and followed by convenience sampling method using the following inclusion criteria: a final years undergraduate student $\left(4^{\text {th }}\right.$ or $5^{\text {th }}$ year) and had a living parent.

\section{Instruments}

A self-administered questionnaire was used to examine the choice of future living arrangement for parents and characteristics of adult children, parents and families. Questions related to living arrangement were adapted from United Nations (2005) living arrangement classification. While, questions related to characteristics of adult children, parents and families were developed from study literature on factors related to elderly parents living arrangement decision.

\section{Data collection}

Research assistants were employed to collect the data. The assistants were undergraduate students who have been trained for data collection process. Prior data collection, participants were given information about the study and the nature of participation which were voluntary. Participants were also assured that their confidentiality and anonymity would be maintained throughout the study. If they agreed to participate, they would sign written inform consent.

\section{Data analysis}

Univariate analysis was used to describe frequency distribution of demographic characteristic of respondent and future living arrangement. Bivariate analysis was used to examine factors associated to living arrangement. Fisher exact test, instead of chi-square test, was used to testing the relationship between variables, since the requirement for chisquare could not be met.

\section{RESULTS \\ Demographic characteristics}

A total of 300 undergraduate students participate in this study. Table 1 showed demographic characteristics of respondent. Almost two third of respondents was female and had 2 or more siblings. According to birth order, about $40 \%$ of respondents were first child in the family.

Table 1. Demographic characteristics of respondents $(n=300)$

\begin{tabular}{|c|c|}
\hline Characteristics & n (\%) \\
\hline \multicolumn{2}{|l|}{ Sex } \\
\hline Female & $195(65)$ \\
\hline Male & $105(35)$ \\
\hline \multicolumn{2}{|l|}{ Number of sibling } \\
\hline $\begin{array}{l}\leq 1 \\
2 \text { or more }\end{array}$ & $\begin{array}{l}110(36.7) \\
190(63.3)\end{array}$ \\
\hline \multicolumn{2}{|l|}{ Birth order } \\
\hline $\begin{array}{l}\text { First child } \\
\text { Other }\end{array}$ & $\begin{array}{l}120(40) \\
180(60)\end{array}$ \\
\hline
\end{tabular}

\section{Living arrangement}

Table 2 describes about future living arrangement for parents. Majority of respondents wanted parents to live at home when they are old $(97.3 \%)$, with children and grandchildren $(84.5 \%)$. Only $2.7 \%$ of respondents considered nursing home as a choice. Those who preferred parents to live with their children, more than two third of them stated that parents could live with any of their children, either son or daughter and either eldest or middle or youngest one $(69.2 \%$ and $82.2 \%$ respectively). Majority of respondents stated that the decision regarding where and with whom their parents would be living in should be made together (80.7\%).

Table 2. Future living arrangement $(n=300)$

\begin{tabular}{lc}
\multicolumn{1}{c}{ Characteristics } & $\mathbf{n}(\%)$ \\
\hline Where should parents be living? & $8(2.7)$ \\
Nursing home & $292(97.3)$ \\
Home & $32(11)$ \\
If live at home, whom parents should be living with? & $247(84.5)$ \\
Alone/spouse only & \\
Children/ children in law/ grandchildren &
\end{tabular}




\begin{tabular}{lc}
\hline \hline \multicolumn{1}{c}{ Characteristics } & $\mathbf{n}(\%)$ \\
\hline Other (not among categories defined above) & $13(4.5)$ \\
If live with children, whom parents should be living & \\
with? & $18(7.3)$ \\
Son & $58(23.5)$ \\
Daughter & $171(69.2)$ \\
Anyone & \\
If live with children, whom parents should be living & \\
with? & $22(8.9)$ \\
First child & $22(8.9)$ \\
Last child & $203(82.2)$ \\
Anyone & \\
Who will decide the arrangement? & $54(18)$ \\
Parents & $4(1.3)$ \\
Children & $242(80.7)$ \\
Together (parents and children) &
\end{tabular}

Factor associated to future living arrangement

Statistical analysis was employed to examine characteristics of the adult children, parents, and families which might influence the preference surrounding future living arrangement of aging parents. Table 3 showed that gender of children was associated to choice of future living arrangement.

Table 3. Factors associated to future living arrangement $(n=292)$

\begin{tabular}{|c|c|c|c|c|}
\hline \multirow[b]{2}{*}{ Characteristics } & \multicolumn{3}{|c|}{ Living Arrangement } & \multirow[b]{2}{*}{$p$} \\
\hline & $\begin{array}{c}\text { Alone/spouse } \\
\text { only }\end{array}$ & $\begin{array}{l}\text { Children/ in } \\
\text { law/ } \\
\text { grandchildren }\end{array}$ & $\begin{array}{c}\text { Other (family/ } \\
\text { non-family } \\
\text { member) }\end{array}$ & \\
\hline \multicolumn{5}{|l|}{ Children gender } \\
\hline Female (daughter) & $22(11.5)$ & $168(87.5)$ & $2(1)$ & \multirow[t]{2}{*}{0.00} \\
\hline Male (son) & $10(10)$ & $79(79)$ & $11(11)$ & \\
\hline \multicolumn{5}{|l|}{ Number of sibling } \\
\hline$\leq 1$ & $12(11.3)$ & $92(86.8)$ & $2(1.9)$ & \multirow[t]{2}{*}{0.27} \\
\hline 2 or more & $20(10.8)$ & $155(83.3)$ & $11(5.9)$ & \\
\hline \multicolumn{5}{|l|}{ Birth order } \\
\hline First child & $9(7.8)$ & $102(87.9)$ & $5(4.3)$ & \multirow[t]{2}{*}{0.35} \\
\hline Other & $23(13.1)$ & $145(82.4)$ & $8(4.5)$ & \\
\hline \multicolumn{5}{|l|}{ Marital status of parent* } \\
\hline Married & $32(12.1)$ & $220(83.0)$ & $13(4.9)$ & \multirow{2}{*}{0.055} \\
\hline Divorced & $0(0)$ & $27(100)$ & $0(0)$ & \\
\hline \multicolumn{5}{|l|}{ Biological status of parent* } \\
\hline Both are biological & $32(11.1)$ & $245(84.7)$ & $12(4.2)$ & \multirow{2}{*}{1.00} \\
\hline One or both step parents & $0(0)$ & $2(66.7)$ & $1(33.3)$ & \\
\hline \multicolumn{5}{|l|}{ Age of parent* } \\
\hline Both aged $<60$ y.o & $29(11.1)$ & $222(84.7)$ & $11(4.2)$ & \multirow[t]{2}{*}{1.00} \\
\hline $\begin{array}{l}\text { Both or one of them } \\
\text { aged } \geq 60 \text { y.o }\end{array}$ & $3(10)$ & 25 (83.3) & $2(6.7)$ & \\
\hline \multicolumn{5}{|l|}{ Parents' health status* } \\
\hline Both in a good health & $26(10.2)$ & $216(85)$ & $12(4.7)$ & \multirow{2}{*}{0.27} \\
\hline One or both not in a & $6(15.8)$ & $31(81.6)$ & $1(2.6)$ & \\
\hline \multicolumn{5}{|l|}{ Family type* } \\
\hline Nuclear & $32(12.1)$ & $221(83.7)$ & $11(4.2)$ & \multirow[t]{2}{*}{0.054} \\
\hline Extended & $0(0)$ & $26(92.9)$ & $2(7.1)$ & \\
\hline \multicolumn{5}{|l|}{ Family economics } \\
\hline Double income & $21(15.4)$ & $110(80.9)$ & $5(3.7)$ & \multirow[t]{2}{*}{0.06} \\
\hline Single/ no income & $11(7.1)$ & $137(87.8)$ & $8(5.1)$ & \\
\hline
\end{tabular}




\begin{tabular}{lcccc}
\hline \hline Characteristics & \multicolumn{3}{c}{ Living Arrangement } & \\
\cline { 2 - 4 } & $\begin{array}{c}\text { Alone/spouse } \\
\text { only }\end{array}$ & $\begin{array}{c}\text { Children/ in } \\
\text { law/ } \\
\text { grandchildren }\end{array}$ & $\begin{array}{c}\text { Other (family/ } \\
\text { non-family } \\
\text { member) }\end{array}$ & $\boldsymbol{p}$ \\
\hline $\begin{array}{c}\text { Type of residence } \\
\text { Urban }\end{array}$ & $24(12.8)$ & $154(81.9)$ & $10(5.3)$ & 0.23 \\
Rural & $8(7.7)$ & $93(89.4)$ & $3(2.9)$ &
\end{tabular}

*"Children/ in law/ grandchildren" and "other (family/ non-family member)" were collapsed and fisher exact test was used to analyzed the data because requirements for chi-squared test could not be meet. \# Non-institutional (home).

\section{DISCUSSION}

This study examined living arrangement for parents in their old age and factors that might influence the choice. Findings showed that living in multi-generational household still become the preference by majority of adult children. Living in institution seems has not yet became an alternative to long term care choice in Indonesia. However, in many developed countries, institutional care has become an option for older persons who have difficulty managing on their own or who need specialized care (United Nations, 2017a).

A possible explanation for this finding might be related to values regarding institutionalization upheld by Indonesian society. A previous qualitative study conducted in Indonesian context found that to put parents in institution like nursing home was perceived as against the value of filial piety which expecting children to fulfill care responsibility for their aging parents (Setiyani, 2012). The concept of filial piety might be largely found in Chinese cultural study contexts, but some studies in other Asian societies also indicated the presence of this concept (Beh \& Folk, 2013; Chan, 2017). There is also a view upheld by the Indonesian society that children who put elderly parents in nursing home would be judged as "un-filial children". Thus, to prevent these negative images, children would try their best to keep the elderly parents stay at home (Setiyani, 2012). However, nowadays the value is undergoing process of reconstruction. A previous study in China context found that elder parents are more willing to accept institutional care. The decision around institutionalization was made primarily as response to family caregiving crisis and to reduce caregiving burden (Chen, 2011).
Risk and benefit of institutionalization might also influence the choice of adult children to care for aging parent at home. A previous study suggested that adult children perceived that living in institution would not give significant benefits for their aging parent, except for physical care (Setiyani, 2012). The belief that institutional care mainly focused on meeting physical needs was resounded in Guo, Konetzka, Magett, \& Dale's study (2014). The study indicated that institutional care was preferred over home care only when older people had severe health status and high level of disability. Preference of home over nursing home for future living arrangement for aging parents would support the implementation of concept of "aging in place". The concept of "aging in place" was aimed at allowing older people to remain at their familiar environment as long as possible and providing appropriate support and service as needed. The implementation of this concept was believed to have several benefits, including maintain identity and well-being of older people and reducing health care cost (Lecovich, 2014).

The present study indicated that many older people in Indonesia would continue living in a multi-generational household. Survey by Badan Pusat Statistik (BPS)/ Indonesian Central Agency on Statistics (2018) suggested that about $70 \%$ of older people were living in multi-generational household. The remaining about $29 \%$ of them was living independently either alone or with spouse only. However, changes in living arrangements of older people took place in many regions. United Nations (2017 $\left.{ }^{a}\right)$ indicated that the number of older people living alone or with spouse only is continue increasing, while those living with children 
is decreasing as a result of considerable changes in demographic, social and economic.

Decision surrounding old-age living arrangement and elderly caregiving was very possible to be influenced by culture. Adult children in this study might be bounded by cultural value and norms which expect them to do so (Setiyani, 2012). A previous study in China context suggested that adult children decide to coreside as they believe that co-residing with elderly parent was an exemplification of filial piety (Zhang et al., 2014).

The decision to co-residence could be also motivated by practical reasons, primarily by parents' needs. However, this study found that no parental factors influence adult children's preference regarding future living arrangement. This was interesting since previous studies indicated that parent's factors were likely to influence the decision for co-residence. For example, Zhang's et al. study (2014) found that adult children were more likely to co-reside with parent who was unmarried, had physical disabilities and was financially dependent. A previous study in Indonesian context also suggested that cohabitation was motivated by parental needs, though it more pronounced in those of mothers (Johar \& Maruyama, 2010). The possible explanation for this contrary finding was that adult children in this study context were prospective caregiver, not the actual ones. Thus it was very possible that they couldn't really predict parent's situation in the future which might influence their decision.

An interesting finding of this study was even though there was different preference of living arrangement between son and daughter, majority of them agreed that parents in their old age could coreside with any children, by disregarding their gender or birth order in the family. Cultural values have also been shown to determine the role of caregiving, particularly who is responsible to care (Pharr, Francis, Terry, \& Clark, 2014). In some cultures, female gender was primarily prescribed for caregiving and the oldest daughter was often assumed the duty (Pharr et al., 2014). In matrilineal society like the Minangkabau, daughter was strongly preferred for care over son. In contrast, daughter was equally preferred as son among Javanese, although some indicated a slight preference for care by daughters (Schröder-Butterfill \& Tengku Syawila, 2014). This study was conducted in a multicultural setting. However, it was very possible that Java ethnicity predominated among study samples and thus influenced the findings.

Findings suggested that decision surrounding living arrangement for parent in their old age was matter of agreement that should be reached by considering both children's and parents' concerns. Coresidence might looks to be an ideal living arrangement for aging parents since it is culturally preferred and enables for exchanging supports. However, previous researches have yielded conflicting evidences regarding effect intergenerational living arrangement on elderly parent's well-being (Jung \& Kim, 2017; Teerawichitchainan et al., 2015). Even a study found a negative effect of self-select co-residence (Johar \& Maruyama, 2014). These studies indicated that for a better outcome, decision for living arrangement should be made carefully by considering needs and expectation of involved parties, cultural norms, and availability of resources.

Few limitations were identified in this study. First, this study was conducted among high educated young adults, thus the conclusion couldn't be applied to those of with lower education level. Education level was more likely to influence financial resources of the adult children and degree of support can be provided to elderly parents (Witoelar, 2012). Cultural background of respondent was not assessed in this study. Different culture might have different prescribed gender role in elderly caregiving.

\section{CONCLUSION}

Living in two or three generation household, with adult children and/ or grandchildren, still became a favorable choice of living arrangement for elderly parents. Living in institution (nursing home) seems not yet considered to an 
alternative for elderly care. Further researches are needed to determine how the choice of living arrangement might influence older people's well-being.

\section{REFERENCES}

Badan Pusat Statistik (BPS). (2018). Statistik Penduduk Lanjut Usia 2018. Jakarta: Badan Pusat Statistik.

Beh, L. S., \& Folk, J. Y. (2013). A study of filial piety practice in Malaysia: relationship between financial wellbeing and filial piety. African Journal of Business Management, 7(38), 3895-3902. https://doi.org/10.5897/ AJBM10.424

Chan, C. (2017). Not always 'left-behind:' Indonesian adolescent women negotiating transnational mobility, filial piety, and care. The Asia Pacific Journal of Anthropology, 18(3), 246263. https://doi.org/10.1080/144422 13.2017.1311372

Chen, L. (2011). Elderly residents' perspectives on filial piety and institutionalization in Shanghai. Journal of Intergenerational Relationships, 9(1), 53-68.

Guo, J., Konetzka, R. T., Magett, E., \& Dale, W. (2014). Quantifying longterm care preferences. Medical Decision Making. https://doi.org/10. 1177/0272989X14551641

Johar, M., \& Maruyama, S. (2010). Intergenerational Cohabitation in Modern Indonesia: Filial Support and Dependence (Australian School of Business Research Paper No. No. 2010 ECON 07). Retrieved from http://ssrn.com/abstract $=1551862$

Johar, M., \& Maruyama, S. (2014). Does coresidence improve an elderly parent's health? Journal of Applied Economics, 29, 965-983. https://doi. org/10.1002/jae.2339

Jung, J., \& Kim, I. (2017). Effects of living arrangements of the urban elderly on their subjective wellbeing: A comparison between Korea and
China. Cogent Social Sciences, 3(1), 1268288. https://doi.org/10.1080/233 11886.2016.1268288

Kadar, K., Francis, K., \& Sellick, K. (2013). Ageing in Indonesia: health status and challenges for the future. Ageing International, 38, 261-270. https:// doi.org/10.1007/s12126-012-9159-y

Lecovich, E. (2014). Aging in place: From theory to practice. Anthropological Notebooks, 20(1), 21-33.

Pharr, J. R., Francis, C. D., Terry, C., \& Clark, M. C. (2014). Culture, caregiving, and health: exploring the influence of culture on family caregiver experiences. ISRN Public Health, 1-8. https://doi.org/10.1155/ $2014 / 689826$

Schröder-Butterfill, E., \& Tengku Syawila, F. (2014). Care dependence in old age: preferences, practices, and implications in two Indonesian communities. Ageing Society, 34(3), 361-387.

https://doi.org/10.1017/S0144686X1 2001006

Setiyani, R. (2012). Exploration of the meaning of filial responsibility among young people in Indonesia. Queensland University of Technology.

Teerawichitchainan, B., Pothisiri, W., \& Long, G. T. (2015). How do living arrangements and intergenerational support matter for psychological health of elderly parents? Evidence from Myanmar, Vietnam, and Thailand. Social Science and Medicine, 136-137, 106-116. https://doi.org/https://doi.org/10.1016 /j.socscimed.2015.05.019

United Nations. (2005). Living Arrangement of Older Persons Around the World. New York.

United Nations. (2017a). Living Arrangement of Older Persons: $A$ Report on an Expanded International Dateset. New York. 
United Nations. (2017b). World Population Ageing. New York.

United Nations Population Fund. (2014). UNFPA Monograph Seriens No.1: Indonesia on the Threshold of Population Ageing. Indonesia.

Weissman, J. D., \& Russell, D. (2018). Relationships between living arrangments and health status among older adults in the United States, 2009-2014: Findings from the National Health Interview Survey. Journal of Applied Gerontology, 37(1), 7-25. https://doi.org/10.1177/07334648166 55439

Witoelar, F. (2012). Household Dynamics and Living Arrangments of the Elderly in Indonesia: Evidence from a Longitudinal Survey. In J. Smith \&
M. Majmundar (Eds.), Aging in Asia: Findings from New and Emerging Data Initiative s. Washington DC: National Academic Press.

Zhang, Z., Gu, D., \& Luo, Y. (2014). Coresidence with elderly parents in contemporary China: the role of filial piety, reciprocity, socioeconomic resources, and parental needs. Journal of Cross Cultural Gerontology, 29, 259-276. https://doi.org/10.1007/s10823-0149239-4

Zhou, Z., Mao, F., Ma, J., Hao, S., Qian, Z., Elder, K., ... Fang, Y. (2018). A longitudinal analysis of the association between living arrangments and health among older adult in China. Researach on Aging, 40(1), 72-97. 